\title{
The problem of insufficient debtor's property during bankruptcy
}

\author{
Igor Valerievich Sarnakov", Aleksandra Vadimovna Sarnakova, Igor Valentinovich \\ Matveev, Natalya Alekseevna Matveeva, and Ekaterina Sergeevna Yulova \\ Financial University under the Government of the Russian Federation, Department of Legal \\ Regulation of Economic Activity, Faculty of Law, Moscow, Russia
}

\begin{abstract}
The purpose of the study is to determine the key factors affecting the occurrence of insufficiency of debtors' property in modern conditions, as well as to formulate the main directions of overcoming them. The methodological basis of the research was the dialectical method of scientific knowledge, general scientific (analysis, synthesis, modeling), and special scientific methods (formal and legal, statistical). The result of the work was the formulation and substantiation of tasks, the setting of which is necessary for further scientific research aimed at increasing the number of satisfied creditors' claims. In addition, the authors identified the elements of the legislatively enshrined bankruptcy mechanism, which require changes to resolve the indicated problem. In particular, the measures proposed by the authors will make it possible to increase the degree of filling the bankruptcy estate by modernizing the procedure for selling the debtor's property, stimulating a more active position of the arbitration administrator to challenge the debtor's transactions, and bringing his controlling persons to subsidiary liability. The novelty of the work lies in the identification of key factors influencing in modern conditions the appearance of signs of insolvency, the quality, and quantity of debtors' assets, the insufficiency of their bankruptcy estate. Among them, objective economic reasons, imperfection of bankruptcy legislation, dishonesty of key participants in legal relations related to bankruptcy (debtor, bankruptcy administrator, majority creditors), unwillingness to use the institution of bankruptcy rehabilitation mechanisms, and the epidemiological situation are highlighted.

Keywords: insolvency (bankruptcy), satisfaction of creditors' claims, bankruptcy estate, bankruptcy commissioner
\end{abstract}

\section{Introduction}

The legitimate interest of the creditor is to receive the satisfaction of his claims, the term of which has already come, but in the event of initiation of a bankruptcy case, the usual procedure is transformed, from that moment the creditor can receive the satisfaction of his claims in the manner established by Federal Law No. 127 - Federal Law “On Insolvency

\footnotetext{
${ }^{*}$ Corresponding author: saival@mail.ru

(Bankruptcy)" [1], adequately and proportionally, according to a certain priority. In practice, however, creditors do not receive the satisfaction of this legitimate interest. So, according to statistics, the number of court decisions on the bankruptcy of citizens in 2020 amounted to 119,049 , and on the bankruptcy of companies - 9,931. At the same time, the share of
} 
bankruptcy cases of citizens in which creditors did not receive anything as a result of the procedure was $67 \%$, and $83.5 \%$ of debtors had no property. In companies, the share of such cases is lower $-60.6 \%$, and according to the inventory of property, $37.2 \%$ of debtors [2] did not have such cases, but it is impossible to speak about the sufficiency of this level of satisfaction of creditors' claims and the availability of the property. But even in those bankruptcy cases where creditors receive some satisfaction for their claims, it has remained unacceptably low over the past years. Moreover, the effectiveness of bankruptcy for creditors is reduced. Thus, according to the results of bankruptcy proceedings completed in $2018,5.2 \%$ of their claims were returned to creditors, in $2019-4.7 \%$ [3], and in $2020-$ $4.4 \%$ ! Moreover, when calculating the specified statistical data, only those claims that were included in the registers of creditors' claims are taken into account; accordingly, a significant number of claims for current payments and out-of-registry claims remain outside the study.

The issues of insolvency (bankruptcy), including the problems of filling the bankruptcy estate, in the domestic legal science were given attention in the works of several Russian scientists [4-9], etc. The authors of this article, supporting the above-named colleagues in general, offer slightly different ways to protect the property rights of creditors in the event of a debtor's bankruptcy. "The creation and proper implementation of the appropriate mechanism is aimed at eliminating and minimizing the risks associated with the violation of the rights and legitimate interests of creditors ..." [10].

Thus, the purpose of this study is to determine the key factors affecting the occurrence of debtors' property insufficiency in modern conditions, as well as to formulate the main directions for overcoming them. To achieve the goal, the authors set the following tasks: to identify the reasons influencing the appearance of signs of insolvency, and the quality and quantity of debtors' assets; substantiate the need to optimize existing and introduce new methods of filling the bankruptcy estate.

\section{Methods}

The research and its results are based on the use of the dialectical method of scientific knowledge, general scientific (analysis, synthesis, modeling), and specific scientific methods (formal-legal, statistical). The dialectical approach supposes considering a phenomenon in development: starting with the reasons for its occurrence, continuing with manifestations and influence on civil circulation, as well as the possibilities of managing the phenomenon in question, or ways of influencing it. The method of scientific analysis concerning the questions raised makes it possible to conditionally split a complex phenomenon into its simpler components and consider them separately, which is used in the study to assess the consequences of the debtor's insolvency for his creditors. Synthesis is a method in which individual elements of cognition are combined into a whole. It allows considering the ways of filling the competitive mass proposed by the authors as a single organism. The formal legal method allows the authors of the article to professionally interpret legislation in the area under consideration and assess the effectiveness of law enforcement. The statistical method makes it possible to identify and compare quantitative indicators for initiated and considered bankruptcy cases, as well as trace the trend of further development of the phenomenon under consideration. The modeling method involves the creation of ways to solve the problem of insufficient property of the debtor to meet the claims of creditors in case of his bankruptcy.

\section{Results and discussion}


The lack of property of insolvent debtors is due to the following reasons, which affect both the appearance of signs of insolvency and the quality and quantity of debtors' assets. Firstly, these are factors traditional for Russian reality, for example, such as high risks in business, poor management, fraudulent actions of the debtor's management, low financial literacy of the population.

Secondly, the factors introduced by the COVID-19 pandemic associated with a decrease in the turnover and income of both entrepreneurs and ordinary citizens. And also the unfair use by debtors of legislative norms on the moratorium: the use of the moratorium by persons who do not have the right to do so, as well as by persons whose insolvency is not related to the pandemic [11].

Thirdly, debtors and creditors see the solution to their problems in the liquidation bankruptcy mechanism. At the same time, the future should be in the rehabilitation of economic entities and the restoration of the financial stability of the citizen, in terms of socio-economic stability and the development of the Russian economy, which will positively affect the problem of satisfying creditors' claims. In this direction, it is proposed to optimize rehabilitation procedures, in terms of weakening the influence of creditors on the possibility of their implementation in case of a positive conclusion of the arbitration manager on the possibility of restoring the debtor's solvency, as well as reanimating pre trial methods of positively influencing the debtor's property status, in particular when using the rehabilitation mechanism. In this direction, it is possible to take into account scientific developments made by such foreign scientists in the field of bankruptcy as [12-14].

Fourth, this is the imperfection of the norms of bankruptcy legislation. An important aspect of the issue is the profitable sale of the debtor's property in the framework of the bankruptcy case, no matter whether the rehabilitation or liquidation procedure has been introduced to the debtor: the inventory procedure, appraisal, sales: public offer, auction, competition ... - aren't those perfect for this purpose? In particular, the problem is that the property is being sold at a much lower cost than it could have been in market conditions. The latter would be beneficial to independent creditors, the debtor, and not to individual interested parties, while the sale costs can be high. This problem is regularly discussed in detail by the tax authorities and is reflected in several scientific articles [15, 16].

The fifth reason is the unfair behavior of the participants in the bankruptcy legal relationship, which is directly aimed at preventing the proportional satisfaction of the claims of all creditors. It is widespread and can be traced both at all stages of the bankruptcy process and before it begins. Thus, the amount of proceeds to the bankruptcy estate gets significantly reduced when preparing a report on the value of the debtor's property that underestimates the initial price, including with the help of friendly expert organizations [17]. It is fairly considered to be an ineffective system for holding tenders, which in practice last more than six months, and at the same time, during all three tenders, it is possible to sell only about $50 \%$ of the debtor's property [5]. It seems reasonable to believe that it is necessary to switch to combined bidding according to the "Dutch auction" system [18].

A more active position of the insolvency administrator in challenging the debtor's transactions, identifying grounds for bringing to subsidiary liability, signs of deliberate and fictitious bankruptcy, should also contribute to the replenishment of funds that are sent to meet current and registry requirements.

The civil liability of the insolvency administrator himself in the event of his inaction or illegal actions in a bankruptcy case performs two functions at once: preventive and compensatory, which also cannot be ignored in the matter of increasing the percentage of creditors' claims satisfaction. 
An increase in the receipt of funds is necessary, but no less important is to reduce current costs, including the payment of the arbitration manager and the services of the persons involved by him, as well as those related to the sale of the debtor's property. There are also frequent cases of an artificial buildup of the current debt to its affiliated persons [19] or the majority creditor by the debtor, to prevent real creditors from obtaining satisfaction of their claims [20]. Transactions with a similar purpose are actively practiced by debtors-citizens [21]. A common way of evading settlements with true creditors is the creation of artificial debt by the debtor in anticipation of insolvency, followed by its inclusion in the register of creditors' claims [22].

An important role in the current negative situation is played by the dishonesty of the insolvency administrator and creditors who have a majority of votes at the meeting of creditors ("majority creditors"). So, practice knows examples when the majority creditor forms the entire composition of the creditors' committee with its representatives [23], which means that such a committee is not able to determine the conditions and procedure for the sale of property, to control transactions, and other actions of the arbitration manager in the interests of all creditors [24].

A separate side of the issue is bankruptcy cases of a citizen. Since although formally all his property constitutes the bankruptcy estate, there is a legally established list of exceptions. In addition, even if the bankruptcy estate includes the maximum possible property and property rights of the debtor-citizen, and (or) the financial manager was able to challenge the debtor's transactions and return the withdrawn property, this will increase the percentage of satisfaction of creditors' claims. In some cases, the property may not exist, or the debtor may lose the ability to work or legal capacity. Therefore, the position of the arbitration court, according to which the mechanism of bankruptcy of citizens is determined as a legal basis for an extraordinary method of releasing the debtor from the fulfillment of the claims (part of the claims) of creditors seems to be fortunate [25]. Thus, the main emphasis should be on preventive measures, and the increasing number of cases is a very dangerous trend.

\section{Conclusion}

The ways of improving the mechanism for filling the bankruptcy estate or stimulating rehabilitation, including pre-trial procedures, expressed by the authors of the study, with further development of legal and economic mechanisms for their implementation will significantly optimize the situation with the protection of the property interests of creditors.

\section{References}

1. Sobranie zakonodatelstva Rossiiskoi Federatsii [Collection of Legislation of the Russian Federation] 43(4190) 2002

2. Statisticheskii byulleten EFRSB na 31 dekabrya 2020 goda [UFRBI Statistical Bulletin as of December 31, 2020]. Accessed on: June 24, 2021. [Online]. Available: http://fedresurs.ru/news/1fc434cc-96ed-4fcb-9ceb-9bb2e3d23adc.

3. Bankrotstva kompanii - statistika Fedresursa za 2019 god [Bankruptcies of companies statistics of the Federal resource for 2019]. Accessed on: June 24, 2021. [Online]. Available: https://fedresurs.ru/news/7b3c8884-b159-4ee7-b5fb-7770d9d941da

4. V.V. Vitryansky (ed.), Nesostoyatelnost (bankrotstvo): Nauchno-prakticheskii kommentarii novell zakonodatelstva i praktiki ego primeneniya [Insolvency 
(bankruptcy): Scientific and practical commentary on novelties of legislation and practice of its application] (Statut, Moscow, 2010)

5. S.A. Karelina, I.V. Frolov (ed.), Institut nesostoyatelnosti (bankrotstva) v pravovoi sisteme Rossii i zarubezhnykh stran: teoriya i praktika pravoprimeneniya: monografiya [Institute of insolvency (bankruptcy) in the legal system of Russia and foreign countries: theory and practice of law enforcement: monograph] (Yustitsinform, Moscow, 2020)

6. R.K. Lotfullin, Challenging the debtor's transactions in bankruptcy Accessed on: June 24, 2021. [Online]. Available: https://m-lawbooks.ru/index.php/product/lotfullin-r-k osparivanie-sdelok-pri-bankrotstve/

7. R.T. Miftakhutdinov, Law, 5, 187-191 (2018)

8. E.D. Suvorov, Bankrotstvo v praktike Verkhovnogo Suda Rossiiskoi Federatsii i Vysshego Arbitrazhnogo suda Rossiiskoi Federatsii: entsiklopediya pravovykh pozitsii za 2014-2018 gg. [Bankruptcy in the practice of the Supreme Court of the Russian Federation and the Supreme Arbitration Court of the Russian Federation: an encyclopedia of legal positions for 2014-2018] (Statut, Moscow, 2019)

9. T.P. Shishmareva, Nedeistvitelnost sdelok i deistvii v protsedurakh nesostoyatel'nosti v Rossii i Germanii [Invalidity of transactions and actions in insolvency proceedings in Russia and Germany] (Statut, Moscow, 2018)

10. A.V. Sarnakova, Lawyer, 4, 60-65 (2020). https://doi.org/10.18572 / 1812-3929-20204-60-65

11. S.S. Galkin, Business Law. App. "Law and Business", 3, 22-30 (2020) 12. V.

Finch, Corporate Insolvency Law. Perspectives and Principles (Cambridge

University Press, Cambridge, 2009)

13. F. Tolmie, Corporate and Personal Insolvency Law (Cavendish Publishing, 2003)

14. J. Westbrook, A Global View of Business Insolvency Systems (Martinus Nijhof Publishers, 2010)

15. A.V. Egorov, Bul. Civil Law, 1, 114-139 (2019). https://doi.org/10.24031 / 1992-20432019-19-1-114-139

16. M.S. Kudinova, Arbitr. Disp. 2, 95-114 (2020)

17. D.O. Osmanova, Zloupotrebleniya pri nesostoyatel'nosti (bankrotstve) [Insolvency (bankruptcy) abuse], in O.A. Belyaeva (ed.) (Yustitsinform, Moscow, 2020) 18. A.G.

Smirnykh, Entrepren. Law, 4, 66-71 (2017)

19. O.M. Sviridenko, Actual Probl. Rus. Law, 2, 105-112 (2020). https://doi.org/10.17803/1994-1471.2020.111.2.105-112

20. Opredelenie Verkhovnogo Suda RF ot 15.10.2018 N 301-ES14-8528(6) po delu № A38-3624/2012, opredelenie Verkhovnogo Suda RF ot 15.06.2018 № 306-ES1517700(9) po delu № A55-27454/2014 [Decision of the Supreme Court of the Russian Federation of October 15, 2018 No. 301-ES14-8528 (6) in case No. A38-3624/2012, decision of the Supreme Court of the Russian Federation of June 15, 2018 No. 306ES15-17700 (9) in case No. A55-27454/2014]. Accessed on: June 24, 2021. [Online]. Available: https://www.garant.ru/

21. Opredelenie Verkhovnogo Suda RF ot 13.06.2019 N 301-ES19-2784(2) po delu N A43-20053/2017 [Decision of the Supreme Court of the Russian Federation of June 13, 2019 No. 301-ES19-2784(2) in case No. A43-20053/2017]. Accessed on: June 24, 
2021. [Online]. Available: https://www.garant.ru/

22. S. Morozov, Legal Work in a Credit Instit., 2, 24-35 (2018)

23. Postanovlenie Devyatogo arbitrazhnogo apellyatsionnogo suda ot 28.02.2019 № 09AP 2988/2019 po delu № A40-38421/13, Opredelenie Verkhovnogo Suda RF ot 25.06.2018 № 304-ES18-7467 po delu № A81-13/2017 [Decision of the Ninth Arbitration Court of Appeal dated February 28, 2019 No. 09AP-2988/2019 in case No. A40-38421/13, decision of the Supreme Court of the Russian Federation dated June 25, 2018 No. 304-ES18-7467 in case No. A81-13/2017]. Accessed on: June 24, 2021. [Online]. Available: https://www.garant.ru/

24. E.S. Yulova, Edu. and Law, 1, 125-130 (2020). https://doi.org/10.24411/2076-15032020-10117

25. Postanovlenie Arbitrazhnogo suda Tsentralnogo okruga ot 20.02.2020 № F101502/2019 po delu № A08-9891/2017 [Resolution of the Arbitration Court of the Central District of 20.02.2020 No. F10-1502/2019 in case No. A08-9891/2017]. Accessed on: June 24, 2021. [Online]. Available: https://www.garant.ru/ 